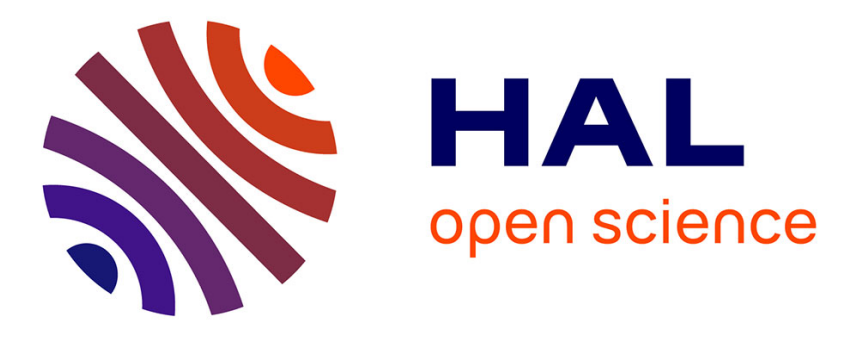

\title{
Quantification of nanoparticle endocytosis based on double fluorescent $\mathrm{pH}$-sensitive nanoparticles
}

Andréa Kurtz-Chalot, Jean-Philippe Klein, Jérémie Pourchez, Delphine

Boudard, Valérie Bin, Odile Sabido, Laurence Marmuse, Michèle Cottier, Valérie Forest

\section{To cite this version:}

Andréa Kurtz-Chalot, Jean-Philippe Klein, Jérémie Pourchez, Delphine Boudard, Valérie Bin, et al.. Quantification of nanoparticle endocytosis based on double fluorescent $\mathrm{pH}$-sensitive nanoparticles. Biomedical Microdevices, 2015, 17 (2), pp.42. 10.1007/s10544-015-9947-8 . hal-01215438

\author{
HAL Id: hal-01215438 \\ https://hal.science/hal-01215438
}

Submitted on 14 Oct 2015

HAL is a multi-disciplinary open access archive for the deposit and dissemination of scientific research documents, whether they are published or not. The documents may come from teaching and research institutions in France or abroad, or from public or private research centers.
L'archive ouverte pluridisciplinaire HAL, est destinée au dépôt et à la diffusion de documents scientifiques de niveau recherche, publiés ou non, émanant des établissements d'enseignement et de recherche français ou étrangers, des laboratoires publics ou privés. 


\section{Quantification of nanoparticle endocytosis based on double fluorescent pH- sensitive nanoparticles}

Andréa Kurtz-Chalot ${ }^{1,2,3}$, Jean-Philippe Klein ${ }^{1,4,5}$, Jérémie Pourchez ${ }^{1,2,3}$, Delphine Boudard $^{1,3,4,5}$, Valérie Bin ${ }^{1,3,4}$, Odile Sabido ${ }^{1,3,4}$, Laurence Marmuse ${ }^{6}$, Michèle Cottier ${ }^{1,3,4,5}$, Valérie Forest* ${ }^{1,2,3}$

${ }^{1}$ LINA Laboratoire Interdisciplinaire d'étude des Nanoparticules Aérosolisées (EA 4624), 15 rue Ambroise Paré, 42023 Saint-Étienne Cedex 2, France.

${ }^{2}$ École Nationale Supérieure des Mines de Saint-Etienne, Centre Ingénierie et Santé, 158 cours Fauriel, CS62362, 42023 Saint-Etienne cedex 2, France.

${ }^{3}$ SFR IFRESIS, Saint-Etienne, France.

${ }^{4}$ Université de Lyon, Université Jean Monnet, Saint-Etienne, France.

${ }^{5}$ CHU de Saint-Etienne, 42055 Saint-Etienne cedex 2, France.

${ }^{6}$ Nano-H, 2 place de l'Europe, 38070 Saint Quentin Fallavier, France.

* Corresponding author: Valérie Forest:

Email address: vforest@emse.fr - Telephone number: +33477499776 


\section{ABSTRACT}

Amorphous silica is a particularly interesting material because of its inertness and chemical stability. Silica nanoparticles have been recently developed for biomedical purposes but their innocuousness must be carefully investigated before clinical use. The relationship between nanoparticles physicochemical features, their uptake by cells and their biological activity represents a crucial issue, especially for the development of nanomedicine. This work aimed at adapting a method for the quantification of nanoparticle endocytosis based on $\mathrm{pH}$-sensitive and double fluorescent particles. For that purpose, silica nanoparticles containing two fluorophores: FITC and pHrodo $^{\mathrm{TM}}$ were developed, their respective fluorescence emission depends on the external $\mathrm{pH}$. Indeed, FITC emits a green fluorescence at physiological $\mathrm{pH}$ and pHrodo $^{\mathrm{TM}}$ emits a red fluorescence which intensity increased with acidification. Therefore, nanoparticles remained outside the cells could be clearly distinguished from nanoparticles uptaken by cells as these latter could be spotted inside cellular acidic compartments (such as phagolysosomes, micropinosomes...). Using this model, the endocytosis of $60 \mathrm{~nm}$ nanoparticles incubated with the RAW 264.7 macrophages was quantified using time-lapse microscopy and compared to that of $130 \mathrm{~nm}$ submicronic particles. The amount of internalized particles was also evaluated by fluorimetry. The biological impact of the particles was also investigated in terms of cytotoxicity, pro-inflammatory response and oxidative stress. Results clearly demonstrated that nanoparticles were more uptaken and more reactive than submicronic particles. Moreover, we validated a method of endocytosis quantification.

Key words: Silica particles, macrophages, size, cellular uptake, cytotoxicity. 


\section{INTRODUCTION}

Amorphous silica is used for many applications because of its chemical stability, its inertness independently of $\mathrm{pH}$ and temperature and its insolubility in water (Merget et al. 2002). The use of amorphous silica has been particularly extended to biomedical applications (Colilla et al. 2008; Santra et al. 2001). And more recently the potential applications of amorphous silica have encompassed the emerging field of nanomedicine (1 to $100 \mathrm{~nm}$ ) (Fang et al. 2011). A great advantage with this material lies in the silane chemistry, allowing versatile surface modifications like addition of specific antibodies or fluorescent probes, resulting in new applications for diagnosis (tumor labeling) (Chandolu and Dass 2013), drug delivery (targeting of cancer cells) (Benezra et al. 2011) or gene transfer (Roy et al. 2005). However, the new physico-chemical properties conferred by the nanometric scale can also potentially trigger a change in the biological behaviour of the nano-objects (Mamaeva et al. 2013; Riehemann et al. 2009). Indeed, at this scale nanoparticles might interact more with cells and consequently be more reactive than bulk material. In vivo studies in mice have shown that materials classically considered as biologically inert (e.g. titanium dioxide, gold or silica) have been reported to cause exacerbated biological responses such as lung inflammation when used at the nanoscale (Kaewamatawong et al. 2005; Oberdörster et al. 2005). More specifically, a study from Cho et al. (2007) on the impact of $14 \mathrm{~nm}$ amorphous silica nanoparticles on lung has shown severe inflammation in mice with, among others, an enhancement of interleukin-6, interleukin-8 and tumor necrosis factor- $\alpha$ (TNF- $\alpha$ ) expressions. These results are reinforced by in vitro toxicological studies. For example Gazzano et al. (2012) have shown a more severe cytotoxicity of 7 and $40 \mathrm{~nm}$ amorphous silica nano-spheres compared to silica micro-spheres on macrophages (MH-S) associated with an enhancement of reactive oxygen species and TNF- $\alpha$ secretion. Nevertheless, previous studies have concluded that cytotoxicity should be studied in parallel to the particles/cells interaction and that the 
intensity of the biological response may be influenced by the amount of internalized particles (Clift et al. 2008).

Cellular internalization processes are known to occur through passive or active transport. As specified in Zhao et al. review (2011), nanomaterials uptake by cells occurs potentially through endocytosis, a general form of active transport in which cytoplasmic membrane engulfs extracellular objects. Endocytosis includes pinocytosis, caveolae-dependent or clathrin-mediated endocytosis and phagocytosis. Most of these pathways lead to the internalization of the extracellular material in vesicles that will progressively acidify. Especially during phagocytosis foreign particles are internalized by vesicles called phagosomes, which fuse with lysosomes, another type of intracellular acidic vesicles, to form phagolysosomes. The $\mathrm{pH}$ is around 6 in a phagosome and decreases to 4.5 in a fully matured phagolysosome (Griffiths 2004). We had already taken advantage of this acidification to investigate cellular particle internalization. Indeed, in a previous study (Leclerc et al. 2012), 250 and $500 \mathrm{~nm}$ silica particles were synthesized including two fluorophores: fluorescein isothiocyanate (FITC) and $\mathrm{pHrodo}^{\mathrm{TM}}$. The respective fluorescence emission of these fluorophores depends on the surrounding $\mathrm{pH}$ : FITC emits a green fluorescence at physiological pH (Ohkuma and Poole 1978), and pHrodo $^{\mathrm{TM}}$ emits a red fluorescence which intensity increases with acidification and that accurately indicates cellular internalization in acidic compartments such as a phagolysosomal localization (Miksa et al. 2009). Therefore, based on the particle $\mathrm{pH}$-sensitivity and double fluorescence, it was possible to quantify cellular particle uptake.

The aim of the present study was to adapt this method to particles of smaller dimensions, including one at the nano-scale. $60 \mathrm{~nm}$ (P60) nanoparticles and $130 \mathrm{~nm}$ (P130) submicronic particles were synthesized. Those dimensions imply to give up previous techniques not enough sensitive and develop a new approach. After a thorough physico-chemical 
characterization these $\mathrm{pH}$-sensitive and double fluorescent particles were incubated with RAW 264.7 macrophages and particle endocytosis was quantified using time-lapse microscopy that furthermore allowed a kinetic follow-up. The amount of internalized particles was also evaluated by fluorimetry using a Trypan Blue quenching method (Leclerc et al. 2010). Finally, cellular response was investigated in terms of loss of cell membrane integrity (determined by the Lactate DeHydrogenase (LDH) assay), pro-inflammatory effect (TNF- $\alpha$ secretion) and oxidative stress (Reactive Oxygen Species (ROS) production).

\section{EXPERIMENTAL PROCEDURES}

\subsection{Reagents}

Tetraethyl orthosilicate $(\mathrm{Si}(\mathrm{OC} 2 \mathrm{H} 5) 4, \mathrm{TEOS}, \geq 99 \%$ ), (3-aminopropyl)triethoxysilane (H2N(CH2)3-Si(OC2H5)3, APTES, 99\%), isopropanol $((\mathrm{CH} 3) 2 \mathrm{CHOH}, \quad \geq \quad 99,5 \%)$, triethylamine $((\mathrm{C} 2 \mathrm{H} 5) 3 \mathrm{~N}, \geq 99,5 \%$, dimethyl sulfoxide anhydrous $((\mathrm{CH} 3) 2 \mathrm{SO}, \mathrm{DMSO}, \geq$ 99,9\%), Fluoresceine isothiocyanate Isomere I (C21H11NO5S, FITC, $\geq 90 \%$ ), sodium hydroxyde $(\mathrm{NaOH})$ were purchased from Aldrich chemical (Sigma-Aldrich Chimie, Lyon, France). Diethylenetriamine pentaacetic dianhydride (C14H19N3O8, DTPA-ba, > 98.0\%) was purchased from TCI Europe (Zwijndrecht, Belgium). pHrodo ${ }^{\mathrm{TM}}$ succinimidyl ester (pHrodo, SE) was purchased from Invitrogen (Cergy Pontoise, France). Ethanol and other organic solvents (reagent grade) were purchased from SDS (France) and used as received.

\subsection{Particle synthesis}

The particles were composed of pure silica core doped with FITC grafted by covalent bonds, as described by Van Blaaderen et al. and Wang et al. (Van Blaaderen and Vrij 1992; Wang et al. 2003). Then a controlled polysiloxane shell (SiOx) with pHrodo $^{\mathrm{TM}}$ probe was added at the core surface, by reacting firstly pHrodo $^{\mathrm{TM}}$ succinimidyl ester with APTES in DMSO. Afterward the resulting product was added to the reaction of hydrolysis condensation 
including APTES/TEOS as organosilane reagent using isopropanol as solvent in the presence of a catalytic amount ot triethylamine (Fizet et al. 2009). Finally the particles were stabilized by introducing carboxylic surface groups $(\mathrm{COOH})$ via diethylenetriamine pentaacetic dianhydride reagent as described in a previous study (Fizet et al. 2009). Briefly, into a suspension of a DTPA-ba in dry DMSO was added a colloidal solution (DMSO) of hybrid particles. The reaction was carried out during 18 hours at room temperature. In order to remove salt and impurities from the suspension, samples were purified against ultrapure water. After an initial centrifugation two series of purification steps composed by subsequent centrifugation and redispersion runs were performed in ethanol and ultrapure water MilliQ $\mathrm{H}_{2} \mathrm{O}$. Finally particles were resuspended in MilliQ $\mathrm{H}_{2} \mathrm{O}$ at $20 \mathrm{~g} / \mathrm{l}$ in $\mathrm{SiO}_{2}$, concentration was controlled by a dry matter measurement. The amorphous and porous properties of the polysiloxane shell allowed the probe accessibility to the environmental $\mathrm{pH}$ variations. The fluorescence change of each type of particle was assessed in buffer solutions at $\mathrm{pH} \mathrm{2,6}$ and 10 by fluorimetry. The particles characteristics are summarized in Table 1 .

\subsection{Physico-chemical characterization of the particles}

Scanning electron microscopy (SEM) images of particles were performed using an ESEM XL30-FEI microscope equipped with a thermal field emission gun (FEG). Dynamic light scattering (DLS) method (nano Zetasizer, Malvern) allowed determining the zeta potential $(\xi)$ and the size distribution of particles. Measures were performed both in distilled water and in the complemented medium DMEMc used for cell culture: Dulbecco's modified Eagle's medium (DMEM, Invitrogen, Cergy Pontoise, France) supplemented with $10 \%$ of fetal calf serum (Invitrogen), 1\% penicillin-streptomycin (penicillin 10,000 units/ml, streptomycin 10 mg/ml, Sigma-Aldrich, Saint-Quentin Fallavier, France).

\subsection{Cell culture}


RAW 264.7 cell line derived from mice peritoneal macrophages transformed by the Abelson murine leukemia virus and was provided by ATCC Cell Biology Collection (Promochem, LGC, Molsheim, France). Cells were cultured in DMEMc at $37^{\circ} \mathrm{C}$ and under a $5 \%$ carbon dioxide humidified atmosphere.

\subsection{Cellular uptake assessment}

\subsubsection{Time-Lapse microscopy}

Macrophages were seeded in a 6-well plate (1 million cells per well) and were allowed to adhere for $4 \mathrm{~h}$. Cell nuclei were stained with $0.1 \mu \mathrm{M}$ of Hoechst 33342 solution (Sigma) for 15 min and rinsed with PBS. Suspensions of P60 and P130 were added at concentration of 30 and $300 \mu \mathrm{g} / \mathrm{ml}$ for $1 \mathrm{~h}$. Then particles were washed in order to reduce background noise. Cells were maintained at $37^{\circ} \mathrm{C}$ and under a $5 \%$ carbon dioxide humidified atmosphere (Heating Unit XL S Zeiss and $\mathrm{CO}_{2}, \mathrm{O}_{2}$ Module). Time-lapse video was performed during 20h (with photography every $30 \mathrm{~min}$ on selected regions) on a numeric inverse microscope platform (Axiovert observer Z1) combined with a fluorescence imaging system. Images were obtained from the fluorescence (excitation, emission) emitted by FITC (488 nm, 495-550 nm), pHrodo (532, 560-650 nm), and Hoechst (350, 408-443 nm) with a HXP 120 lamp and 3 filters (Cy3,

GFP, CFP, through COLIBRI mode). A semi-quantitative analysis was conducted after the observation of 30 cells in order to determine the particle localization within cells. Cell viability was also estimated over time and the reported amount of dying macrophages took into account the cells detached from the well surface. Image analyses were performed with the Fiji distribution of the ImageJ software (Schindelin et al. 2012). The video was used as a stack of images taken over time.

\subsubsection{Fluorimetric analysis}

Macrophages were seeded in 96-well plates (100 000 cells in $200 \mu 1$ of media per well). Cells were allowed to adhere for $4 \mathrm{~h}$ and were incubated with $10,30,60$ and $300 \mu \mathrm{g} / \mathrm{ml}$ of 
suspension of P60 or P130 for 20h. The amounts of particles remained in cell culture supernatant, of particles adhering to cell membrane and of particles uptaken by cells were determined by measuring the green fluorescence emitted by FITC with a fluorometer (Fluoroskan Ascent, Thermolabsystems, France) and using a "trypan blue quenching" (TB) method described elsewhere (Leclerc et al. 2010). Briefly, in addition to its principal function as an exclusion dye of dead cells, TB is known for its ability to "turn off" the green fluorescence emitted by FITC-labeled particles remained outside the cells (Van Amersfoort and Van Strijp 1994; Nuutila and Lilius 2005). This process allowed distinguishing the fluorescence of internalized particles from those of particles just adhering to the cell membrane. For quantification, the fluorescence intensity was reported to a standard curve previously established for each particle concentration. Control wells without particles were used to assess the autofluorescence of cells in culture media.

\subsection{Cytotoxicity assays}

\subsubsection{Cell/particles contacts}

For LDH, TNF- $\alpha$ and ROS assays, macrophages were seeded in 96-well plates (100 000 cells in $200 \mu \mathrm{l}$ of media per well). Then cells were allowed to adhere for $4 \mathrm{~h}$ and were incubated with $10,30,60$ and $300 \mu \mathrm{g} / \mathrm{ml}$ of particles suspension for $20 \mathrm{~h}$ excepted for the detection of ROS, that is an early reaction (Chen et al. 2011), for which cells were incubated with particle suspension for $90 \mathrm{~min}$.

\subsubsection{Cell membrane integrity}

The release in the cell culture supernatant of the cytoplasmic lactate dehydrogenase (LDH) from cells with damaged membranes was assessed using the CytoTox-96 ${ }^{\mathrm{TM}}$ Homogeneous Membrane Integrity Assay (Promega, Charbonnières les Bains, France) according to the manufacturer's instructions. The optical density of the samples was determined using a microplate reader (Multiskan RC; Thermolabsystems, Helsinki, Finland) set to $450 \mathrm{~nm}$. The 
activity of the released LDH was reported to that of total cellular LDH (measured after the lysis of control cells) and was expressed as a percent of the control.

\subsubsection{Pro-inflammatory effect}

After incubation with particles, the secretion of TNF- $\alpha$ was assessed in the supernatant using a commercial ELISA Kit (Quantikine ${ }^{\circledR}$ Mouse TNF- $\alpha$ Immunoassay; R\&D Systems, Lille, France) according to the manufacturer's instructions. The optical density of each sample was determined using a microplate reader (Multiskan RC; Thermolabsystems, Helsinki, Finland) set to $450 \mathrm{~nm}$. A standard curve was established, and results were expressed in picograms per milliliter of TNF- $\alpha$. Each experiment included controls: cells alone (negative control) and DQ12 quartz (toxicological positive control) (Bruch et al. 2004).

\subsubsection{Oxidative stress}

A large array of reactive oxygen species (ROS) activity can be assessed with the OxiSelect ${ }^{\mathrm{TM}}$ ROS Assay Kit (Euromedex, Mundolsheim, France). The assay uses a non-fluorescent substrate, 2.7'-dichlorodihydrofluorescein diacetate, that can easily diffuse through cell membranes and be converted into a fluorogenic molecule $2^{\prime} .7^{\prime}$-dichlorodihydrofluorescein (DCF) in the presence of ROS and which fluorescence is proportional to the total ROS level. DCF production was detected using a Fluoroskan Ascent fluorometer (Thermolabsystems) using excitation and emission wavelengths of 480 and $530 \mathrm{~nm}$ respectively, and the generation of ROS was expressed as nanomolar.

\subsection{Expression of the results}

For nanoparticle distribution determined by fluorimetry, the LDH and TNF- $\alpha$ assays, particles doses were expressed either using mass or surface doses. Surface doses were calculated from mass doses. We knew that the initial concentration of particles solutions was $20 \mathrm{~g} / \mathrm{l}$ and that this concentration corresponded to $8 \times 10^{13}$ particles $/ \mathrm{ml}$ for $\mathrm{P} 60$ and $6 \times 10^{12}$ particles $/ \mathrm{ml}$ for P130 (data provided by the chemists who synthesized the particles). From these data we could 
calculate the weight of one particle, for instance one P60 weighted $2.5 \times 10^{-10} \mu \mathrm{g}$. Then, we considered particles as spherical and we calculated their surface area, using the formula $4 \pi r^{2}$, where $r$ was determined from SEM measurement. For example, for P60, the diameter measured using SEM was $62 \mathrm{~nm}$, therefore, $\mathrm{r}=31 \mathrm{~nm}$. Surface area $=4 \pi^{*}(31)^{2} \approx 12000 \mathrm{~nm}^{2}$. $10 \mu \mathrm{g} / \mathrm{ml}$ (the first tested mass dose) contained $4 \times 10^{10}$ particles $/ \mathrm{ml}$. As each particle had a surface area about $12000 \mathrm{~nm}^{2}$, the total particle surface area in this sample was $4 \times 10^{10} \mathrm{x}$ $12000=48 \times 10^{13} \mathrm{~nm}^{2} / \mathrm{ml}$. As a well contained $200 \mu \mathrm{l}$, the surface dose was $9.6 \times 10^{13} \mathrm{~nm}^{2} /$ well $\approx 1 \mathrm{~cm}^{2} /$ well. These calculations were made similarly for each dose. Finally to compare comparable surface doses between P60 and P130, the mass dose of $10 \mu \mathrm{g} / \mathrm{ml}$ for P60 was compared to the mass dose of $30 \mu \mathrm{g} / \mathrm{ml}$ for P130, each corresponding to a surface dose of 1

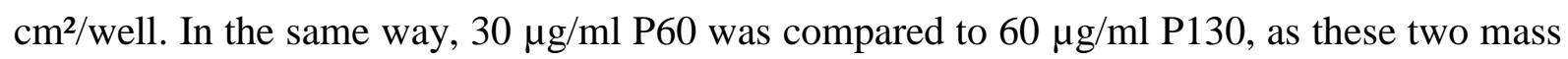
doses corresponded approximately to a surface dose of $3 \mathrm{~cm}^{2} /$ well.

\subsection{Statistical analysis}

Analysis and graphics were performed on Prism 5.0 software (GraphPad, San Diego, CA). Significance was established with Bonferroni's Multiple Comparison Test, (1) Two-wayANOVA test (compared to negative control: cells alone) and data considered significant with $P<0.05$ are marked with an asterisk (*) sign, and (2) One-way-ANOVA (particle compared with each other) and data considered significant with $P<0.05$ are marked with a sign as specified in each figure legend. Each data point represents the mean of three independent experiments $(n=3)$ and is presented with the arithmetic standard error means $( \pm$ s.e.m.).

\section{RESULTS}

\subsection{Particle characterization}

Geometric diameters were measured from SEM images and hydrodynamic diameters were measured using DLS. These data, including zeta potential, are reported in Table 2. 
The hydrodynamic diameters of P60 and P130 measured in DMEMc were correlated with the geometric diameters but small agglomerates clearly appeared in water. Zeta-potentials of the two kinds of particles were similar in water and in DMEMc.

\subsection{Particle uptake by macrophages}

\subsubsection{Time-lapse microscopy}

Macrophages were incubated either with 30 or $300 \mu \mathrm{g} / \mathrm{ml}$ particles for $1 \mathrm{~h} .30 \mu \mathrm{g} / \mathrm{ml}$ appeared to be a too low concentration to allow the detection of the particles fluorescence. On the contrary, and as reported in Fig. 1, images for the $300 \mu \mathrm{g} / \mathrm{ml}$ particle dose showed changes in fluorescence emission due to the two fluorophores (green FITC and red pHrodo) emitting their fluorescence depending on $\mathrm{pH}$. Uptake of particles by cells was determined by the color of fluorescence emission. Initially, particles were outside the cells and only a green fluorescence was emitted. Then particles were uptaken and pHrodo emitted a red fluorescence more intense within acidic vesicles. Macrophages appeared yellow due to the merge of green and red fluorescences. Because phagolysosomes are more acidic than phagosomes, macrophages clearly became orange to red depending on the process stage of uptake and acidification of medium around particles. For both particles, the color change was found to be reversible as released particles after loss of membrane integrity and cell death became green again.

Based on these observations, a semi-quantification of cellular particle uptake was carried out and is reported in Table 3. T2, T8, T15 and T20 were respectively the $2^{\text {nd }}, 8^{\text {th }}, 15^{\text {th }}$ and $20^{\text {th }}$ hours after particles/cells contact. Cells morphology and particles color allowed determining the stage of particle endocytosis. Activated cells presented cytoplasmic extensions. Dying cells became spherical and did not adhere to the bottom of the well. Globally cell viability decreased faster after contact with P60 (63\%, 20\% and 10\% of living cells at T8, T15 and T20 respectively) than after contact with $\mathrm{P} 130(82 \%, 70 \%$ and $56 \%$ of living cells at T8, T15 and 
T20 respectively). P60 emitted red fluorescence earlier (around T2) than P130 (around T8) and seemed homogeneously distributed in cell cytoplasm. Macrophages after contact with P130 appeared filled of green and yellow to orange vesicles but vesicles did not become clearly red certainly due to the particles intrinsic property as shown in graphics of Table 1 (right column).

To better estimate and quantify the changes occurring over time, the FITC/pHrodo fluorescence intensities ratio was measured for one isolated cell during the $20 \mathrm{~h}$ of incubation with particles. For that purpose, a two-step process was carried out: first, and as illustrated in Fig. 2a, a region of interest containing one isolated cell was selected on the first image of the stack of images obtained from the video. Then images were analyzed depending on four channels: phase contrast (to observe cell morphology), blue fluorescence (Hoechst emission), green fluorescence (FITC emission) and red fluorescence (pHrodo emission). The means of green and red intensities (Fig. 2b) for the region of interest were measured, and then the green per red ratio, i.e. the FITC/pHrodo ratio, was calculated for each time point and reported in Fig. 2c. It clearly appeared that for P60, as well as for P130, FITC/pHrodo ratios decreased at early time due to the particle endocytosis, and then ratios increased due to the particle release. Indeed, due to the loss of membrane integrity that accompanied cell death, internalized particles were released in the extracellular environment where the $\mathrm{pH}$ is higher than in intracellular vesicles, consequently, particles turned green. This observation is consistent with cell viability: P130 ratio increase began after 8 hours of particles/cells contact, later than that of P60 (after 6 hours) suggesting that cell death occurred earlier after contact with P60 than after contact with P130.

To further confirm these results, an average FITC/pHrodo ratio was calculated from measures from 5 isolated cells exhibiting a loss of cell membrane integrity. The mean ratios for P130 and P60 are given in Fig. 3. As cells incubated with P60 and cells incubated with P130 did not 
die at the same moment, the starting point of the graphic is different: T8 for P130 and T6 for P60. Results confirmed the FITC/pHrodo ratio increase during cell death corresponding to particles release.

\subsubsection{Fluorimetry}

Cellular uptake was then quantified using fluorimetry as reported in Fig. 4. The amount of nanoparticles in supernatant, adsorbed at cell surface or uptaken by cells were determined at different doses. In Fig. 4a results are expressed depending on particle mass $(\mu \mathrm{g} / \mathrm{ml})$. It appeared that particles mainly remained in the supernatant whatever the size. Moreover uptake was found to be dose-dependent irrespective of the particle size and the amount of uptaken P60 was significantly higher than that of P130 at each dose. For both particles, adsorption of particles at the cell membrane was found to be globally constant and the amount of P60 adsorbed at the cell surface was significantly higher than the amount of adsorbed P130 at each dose. As reported in Fig. 4b, same conclusions were reached when results were expressed depending on particle surface area per well $\left(\mathrm{cm}^{2} /\right.$ well).

\subsection{Cytotoxicity}

\subsubsection{Cell membrane integrity}

Cytotoxicity depending on particle mass $(\mu \mathrm{g} / \mathrm{ml})$ is reported in Fig. 5a. The LDH release triggered by P60 was significantly different from that of control cells (incubated without nanoparticles) from the dose of $60 \mu \mathrm{g} / \mathrm{ml}$, while the LDH release triggered by P130 was significantly different from that of control cells only at the highest dose of $300 \mu \mathrm{g} / \mathrm{ml}$. At this dose the LDH release triggered by P60 and P130 were similar. In Fig. 5b results are expressed depending on particle surface area per well $\left(\mathrm{cm}^{2} /\right.$ well $)$ and show no cytotoxicity at the tested doses. 


\subsubsection{Pro-inflammatory effect}

The pro-inflammatory effect induced by the particles is shown in Fig. 6. In Fig. 6a results are expressed depending on particle mass ( $\mu \mathrm{g} / \mathrm{ml})$. Basal level of TNF- $\alpha$ secretion was increased in a dose-dependent manner by the presence of positive control (quartz DQ12). The TNF- $\alpha$ secretion triggered by P60 was dose-dependent and significantly different from that of control cells (incubated without nanoparticles) from the dose of $60 \mu \mathrm{g} / \mathrm{ml}$. TNF- $\alpha$ secretion triggered by P130 was dose-dependent too and significantly different from that of control cells only at the highest dose of $300 \mu \mathrm{g} / \mathrm{ml}$. At this dose TNF- $\alpha$ secretion triggered by P60 was higher than that triggered by P130 and DQ12. In Fig. 6b results are expressed depending on particle surface area per well $\left(\mathrm{cm}^{2} /\right.$ well $)$ and show a dose-dependent pro-inflammatory response similar between P60 and P130.

\subsubsection{Oxidative stress}

No significant oxidative stress was detected when cells were incubated with the different types of nanoparticles. Relative quantification of ROS probe DCF in cells in contact with P60 or P130 was around $77 \pm 16 \mathrm{nM}$ (data not shown) and was not statistically different from $62 \pm 11 \mathrm{nM}$ detected for control cells.

\section{DISCUSSION}

This work aimed at adapting a method to quantify the endocytosis of particles at the nanoscale in parallel to the assessment of their potential cytotoxicity. Many toxicological studies on silica particles have been reported, however, the literature often reports contradictory conclusions (Stark 2011). This is sometimes due to a lack of sufficient particles characterization. Indeed, many particles features may be affected by the chemistry of their surroundings and the presence of inorganic and biological components (Leclerc et al. 2010; Van Blaaderen and Vrij 1992). This is why, in this study, particles (complying with very strict 
and standardized guidelines) were thoroughly characterized in water and in cell culture medium DMEMc by dynamic light scattering instrument (Table 2) before any experiments. Absence of agglomeration in DMEMc supplemented with serum may be due to the formation of a protein corona around particles causing steric hindrance (Barrán-Berdón et al. 2013). This hypothesis was already demonstrated by Sabuncu et al. (2012) comparing agglomeration of $10 \mathrm{~nm}$ gold nanoparticles (functionalized with carboxylic acid groups) in water and DMEM with and without serum.

Particles with a double fluorescence and sensitive to environmental $\mathrm{pH}$ changes were developed to take advantage of the property of acidification of endocytic vesicles. Different systems have already been described in the literature such as PEBBLEs or capsules (fluorescent microcapsules) to detect different cellular processes regulated by intracellular $\mathrm{pH}$ (e.g., apoptosis, phagocytosis, cell growth, and metabolism) (Peng et al. 2007; Lee and Kopelman 2012). However, these existing systems were not appropriate for this study in the sense that the FITC/pHrodo particles developed here do not have to be coupled with $\mathrm{pH}$ sensors such as SNARF dye and are directly detected once engulfed in acidic vesicles such as phagolysosomes (Ramshesh and Lemasters 2012; Nakata et al. 2010). Thus, they are appropriate to localize particles in any type of acidic compartment during endocytosis. Furthermore, the aim of this study was not to monitor precise $\mathrm{pH}$ changes, but rather to understand nanoparticle fate inside cells depending of its physico-chemical features. This is why it was important to test different particle sizes that are characteristics difficult to manage for PEBBLEs.

The double fluorescent FITC/pHrodo particles have already been developed in our laboratory but they were not strictly speaking nano-sized (250 and $500 \mathrm{~nm}$ ) (Ohkuma and Poole 1978). Particle synthesis was optimized in order to compare nanoparticles of $60 \mathrm{~nm}$ and submicronic particles of $130 \mathrm{~nm}$. The synthesis of particles with such dimensions was a part of the 
technical challenge. Moreover those dimensions imply to give up previous techniques not enough sensitive and face a new technologic complexity in order to quantify nanoparticle endocytosis. In this study an original qualitative observation based on time-lapse microscopy (Fig. 1) confirmed the endocytosis by macrophages of both studied particles at high dose of $300 \mu \mathrm{g} / \mathrm{ml}$. However, once engulfed P60 emitted a clearly red fluorescence while P130 emitted an orange fluorescence. It was certainly due to intrinsic property of particles shown in Table 1. Indeed under pH 4 FITC/pHrodo ratio for P60 decreased allowing a red color, while FITC/pHrodo ratio for P130 stabilized allowing only orange color at low $\mathrm{pH}$. A quantitative approach based on FITC/pHrodo ratio was used to define profiles of endocytosis of particles (Fig. 2). Interestingly, P60 and P130 did not exhibit the same endocytosis profiles and P60 triggered an early death of cells. Moreover P60 appeared homogeneously distributed in cell cytoplasm while macrophages appeared filled of vesicles after contact with P130. This difference might suggest that other factors may play a role in particles fate within the cell depending on the size of the particles. Nonetheless results showed that, once engulfed, particles were in acidic compartments. Another hypothesis could be that bigger particles were certainly engulfed in bigger vesicles more observable. Profiles of particle release after loss of membrane integrity and cell death were similar between P60 and P130 (Fig. 3).

In order to quantify the amount of internalized particles a trypan blue quenching method was used. This method allowed distinguishing FITC fluorescent particles uptaken from particles adsorbed at the cell membrane (Fig. 4). Interestingly, P60 and P130 did not exhibit the same uptake profiles. P60 were the particles the most adsorbed at the cell surface and the most uptaken. For both particles uptake was dose-dependent while adsorption at cell surface was constant at low doses and strongly increased at high dose of $300 \mu \mathrm{g} / \mathrm{ml}$. Table 3 revealed that cell viability was extremely lower after a 15 hours contact with P60 than with P130. Consistent with this hypothesis was the fact that P60 induced a significant loss of membrane 
integrity (Fig. 5a) and a secretion of TNF- $\alpha$ (Fig. 6a) higher than P130 at the highest dose of $300 \mu \mathrm{g} / \mathrm{ml}$ even if both particles induced a dose-dependent cell response. Results highlight that nanoparticles are more uptaken by cells and more cytotoxic than sub-micronic particles. Complementary studies should be performed to deepen the relationship between the amount of uptaken particles and the cellular response.

No significant oxidative stress was detected which is consistent with a similar study carried out by Panas et al. (2013) where the same cell type RAW264.7 macrophages were incubated with engineered silica nanoparticles of $25 \mathrm{~nm}$ diameter.

Those results are in agreement with literature data showing that in "safer by design" approaches in nanomedicine, particle size is a crucial parameter to take into consideration to understand particle fate inside cells (Gazzano et al. 2012; Greish et al. 2012; Albanese et al. 2012).

Nonetheless, results expressed depending on particles surface area revealed that P60 were more adsorbed at cell surface but profiles of particle uptake (Fig. 4b), cytotoxicity (Fig. 5b) and pro-inflammatory effect (Fig. 6b) were similar for both particles at the same dose. As the size of a particle is related to its surface area, for a given mass of particles the total surface area increases with decreasing particle diameter. Particle size is thereby an essential determinant of the fraction of reactive groups on particle surface (Van Amersfoort and Van Strijp 1994). For those reasons SCENIHR committee (Scientific Committee on Emerging and Newly Identified Health Risks) suggests another definition of nanoparticle than the ISO referential by volume specific surface area above $60 \mathrm{~m}^{2} / \mathrm{cm}^{3}$ independent of the density or size distribution of the material. Finally it appears that data comparison is made more difficult depending on the choice of metric, a crucial point when analysing nanoparticle size impact (Oberdörster et al. 2005). For example, a study from Water et al. (2009), conducted using a whole genome microarray analysis after a cell exposure to 10 and $500 \mathrm{~nm}$ particles, concluded 
that the magnitude of change for the majority of the genes affected correlated more tightly with particle surface area than either particle mass or number.

\section{CONCLUSION}

This study aimed at developing double fluorescent particles $\mathrm{pH}$-sensitive for biological investigations of endocytosis. We presented a proof-of-concept that was validated in cellular conditions. These particles, which physico-chemical characteristics were well-defined and controlled (fluorescence, size, surface coating, and state of agglomeration), induced different cellular responses. Compared by mass, submicronic particles were the less cytotoxic particles and the less significantly uptaken, suggesting that nanoparticle cytotoxicity might be related to their uptake. Importantly, our findings expressed by surface area instead of mass suggest that biological activity of particles might be related to the particle specific surface. But both particles were cytotoxic at the highest dose.

Further investigations are needed to better understand how nano-scale may impact biological responses of silica particles in order to provide a "safer by design" approach for the engineering of new nano-objects. This model of particles may be helpful for a better understanding of uptake mechanisms, a key issue in nanotoxicology.

\section{ACKNOWLEDGEMENT}

The authors would like to acknowledge the financial support of the Région Rhône-Alpes and the Conseil Général de la Loire.

\section{CONFLICT OF INTEREST}

The authors declare that they have no conflict of interest. 


\section{REFERENCES}

A. Albanese, P. S. Tang, W. C. W. Chan, Annu. Rev. Biomed. Eng. 14, 1 (2012)

A. L. Barrán-Berdón, D. Pozzi, G. Caracciolo, A. L. Capriotti, G. Caruso, C. Cavaliere, A. Riccioli, S. Palchetti, A. Laganà, Langmuir ACS J. Surf. Colloids. 29, 6485 (2013)

M. Benezra, O. Penate-Medina, P. B. Zanzonico, D. Schaer, H. Ow, A. Burns, E. DeStanchina, V. Longo, E. Herz, S. Iyer, J. Wolchok, S. M. Larson, U. Wiesner, M. S. Bradbury, J. Clin. Invest. 121, 2768 (2011)

J. Bruch, S. Rehn, B. Rehn, P. J. A. Borm, B. Fubini, Int. J. Hyg. Environ. Health. 207, 203 (2004)

V. Chandolu, C. R. Dass, Curr. Drug Discov. Technol. 10, 170 (2013)

B. Chen, Y. Liu, W. M. Song, Y. Hayashi, X. C. Ding, W. H. Li, Biomed. Environ. Sci. BES. $24,593(2011)$

W. S. Cho, M. Choi, B. S. Han, M. Cho, J. Oh, K. Park, S. J. Kim, S. H. Kim, J. Jeong, Toxicol. Lett. 175, 24 (2007)

M. J. D. Clift, B. Rothen-Rutishauser, D. M. Brown, R. Duffin, K. Donaldson, L. Proudfoot, K. Guy, V. Stone, Toxicol. Appl. Pharmacol. 232, 418 (2008)

M. Colilla, M. Manzano, M. Vallet-Regí, Int. J. Nanomedicine. 3, 403 (2008)

J. Fang, H. Nakamura, H. Maeda, Adv. Drug Deliv. Rev. 63, 136 (2011)

J. Fizet, C. Rivière, J. L. Bridot, N. Charvet, C. Louis, C. Billotey, M. Raccurt, G. Morel, S. Roux, P. Perriat, O. Tillement, J. Nanosci. Nanotechnol. 9, 5717 (2009)

E. Gazzano, M. Ghiazza, M. Polimeni, V. Bolis, I. Fenoglio, A. Attanasio, G. Mazzucco, B. Fubini, D. Ghigo, Toxicol. Sci. Off. J. Soc. Toxicol. 128, 158 (2012)

K. Greish, G. Thiagarajan, H. Herd, R. Price, H. Bauer, D. Hubbard, A. Burckle, S. Sadekar, T. Yu, A. Anwar, A. Ray, H. Ghandehari, Nanotoxicology. 6, 713 (2012)

G. Griffiths, Trends Cell Biol. 14, 343 (2004) 
T. Kaewamatawong, N. Kawamura, M. Okajima, M. Sawada, T. Morita, A. Shimada, Toxicol. Pathol. 33, 743 (2005)

L. Leclerc, D. Boudard, J. Pourchez, V. Forest, O. Sabido, V. Bin, S. Palle, P. Grosseau, D. Bernache, M. Cottier, Inhal. Toxicol. 22, 1091 (2010)

L. Leclerc, D. Boudard, J. Pourchez, V. Forest, L. Marmuse, C. Louis, V. Bin, S. Palle, P.

Grosseau, D. Bernache-Assollant, M. Cottier, J. Nanoparticle Res. 14, 1 (2012)

Y.-E. K. Lee, R. Kopelman, Methods Enzymol. 504, 419 (2012)

V. Mamaeva, C. Sahlgren, M. Lindén, Adv. Drug Deliv. Rev. 65, 689 (2013)

R. Merget, T. Bauer, H. Küpper, S. Philippou, H. Bauer, R. Breitstadt, T. Bruening, Arch. Toxicol. 75, 625 (2002)

M. Miksa, H. Komura, R. Wu, K. G. Shah, P. Wang, J. Immunol. Methods. 342, 71 (2009)

E. Nakata, Y. Yukimachi, Y. Nazumi, Y. Uto, H. Maezawa, T. Hashimoto, Y. Okamoto, H. Hori, Chem. Commun. Camb. Engl. 46, 3526 (2010)

J. Nuutila, E.-M. Lilius, Cytom. Part J. Int. Soc. Anal. Cytol. 65, 93 (2005)

G. Oberdörster, E. Oberdörster, J. Oberdörster, Environ. Health Perspect. 113, 823 (2005)

S. Ohkuma, B. Poole, Proc. Natl. Acad. Sci. U. S. A. 75, 3327 (1978)

A. Panas, C. Marquardt, O. Nalcaci, H. Bockhorn, W. Baumann, H.-R. Paur, S. Mülhopt, S. Diabaté, C. Weiss, Nanotoxicology 7, 259 (2013)

J. Peng, X. He, K. Wang, W. Tan, Y. Wang, Y. Liu, Anal. Bioanal. Chem. 388, 645 (2007)

V. K. Ramshesh, J. J. Lemasters, Methods Mol. Biol. Clifton NJ . 810, 243 (2012)

K. Riehemann, S. W. Schneider, T. A. Luger, B. Godin, M. Ferrari, H. Fuchs, Angew. Chem. Int. Ed Engl. 48, 872(2009)

I. Roy, T. Y. Ohulchanskyy, D. J. Bharali, H. E. Pudavar, R. A. Mistretta, N. Kaur, P. N. Prasad, Proc. Natl. Acad. Sci. U. S. A. 102, 279 (2005) 
A. C. Sabuncu, J. Grubbs, S. Qian, T. M. Abdel-Fattah, M. W. Stacey, A. Beskok, Colloids Surf. B Biointerfaces 95, 96 (2012)

S. Santra, P. Zhang, K. Wang, R. Tapec, W. Tan, Anal. Chem. 73, 4988 (2001)

J. Schindelin, I. Arganda-Carreras, E. Frise, V. Kaynig, M. Longair, T. Pietzsch, S. Preibisch, C. Rueden, S. Saalfeld, B. Schmid, J.-Y. Tinevez, D. J. White, V. Hartenstein, K. Eliceiri, P. Tomancak, A. Cardona, Nat. Methods. 9, 676 (2012)

W. J. Stark, Angew. Chem. Int. Ed. 50, 1242 (2011)

E. S. Van Amersfoort, J. A. Van Strijp, Cytometry. 17, 294 (1994)

A. Van Blaaderen, A. Vrij, Langmuir. 8, 2921 (1992)

W. Wang, B. Gu, L. Liang, W. Hamilton, J. Phys. Chem. B. 107, 3400 (2003)

K. M. Waters, L. M. Masiello, R. C. Zangar, B. J. Tarasevich, N. J. Karin, R. D. Quesenberry, S. Bandyopadhyay, J. G. Teeguarden, J. G. Pounds, B. D. Thrall, Toxicol. Sci. 107, 553 (2009)

F. Zhao, Y. Zhao, Y. Liu, X. Chang, C. Chen, Y. Zhao, Small Weinh. Bergstr. Ger. 7, 1322 (2011) 


\section{FIGURE CAPTIONS}

\section{Fig. 1}

Automated time-lapse microscopy imaging of RAW 264.7 cells incubated for $20 \mathrm{~h}$ with $300 \mu \mathrm{g} / \mathrm{ml}$ P60 or P130. Images were obtained using different channels: phase contrast (to observe cell morphology and membrane integrity), blue fluorescence (to detect Hoechstlabeled nuclei), green fluorescence (reporting particle adsorption at cell surface) and red fluorescence (indicating cellular uptake of particles). When channels were merged, particles could appear from green to red through yellow (due to the red and green fluorescence merge) depending on the surrounding $\mathrm{pH}$. Continue arrows indicate living cells and dotted arrows point cells with a loss of membrane integrity

\section{Fig. 2}

a) Images from time-lapse microscopy of RAW 264.7 cells after incubation with $300 \mu \mathrm{g} / \mathrm{ml}$ P130. A single cell was selected (dotted square) and followed over time. b) Enlargement of the previously selected cell (the same thing was done with P60). Only the merge image of FITC and pHrodo signals allowed distinguishing endocytosed particles (that appeared yellow due to the merge of green and red fluorescences). It also allowed detecting the particle release outside the cells (green due to the lack of red pHrodo signal) during the cell death as it was accompanied by loss of membrane integrity. c) Automated measurement of the FITC/pHrodo ratio changes during 20 hours by software

\section{Fig. 3}

Average FITC/pHrodo ratio changes during cellular loss of membrane integrity (average ratios from 5 isolated cells). To compare comparable things, the starting point of the graphic 
corresponds to the beginning of cell death, therefore it is different for P60 and P130 (i.e. T6 and $\mathrm{T} 8$ respectively)

\section{Fig. 4}

P60 and P130 were incubated for 20h with RAW264.7 macrophages and the distribution of particles was assessed by fluorimetry and Trypan Blue quenching. Results are presented using different metrics: a) particle mass $(\mu \mathrm{g} / \mathrm{ml})$ and b) particle surface area per well $\left(\mathrm{cm}^{2} /\right.$ well). The doses of 1 and $3 \mathrm{~cm}^{2} /$ well roughly correspond to the doses of 10 and $30 \mu \mathrm{g} / \mathrm{ml}$ for P60 and 30 and $60 \mu \mathrm{g} / \mathrm{ml}$ for P130 respectively. (n=3) $(\diamond$ and $\diamond$ indicate statistical differences in particle uptake and adsorption at cell surface respectively)

\section{Fig. 5}

Cytotoxicity of P60 and P130 investigated using the LDH assay in RAW 264.7 macrophages. Results are presented using different metrics: a) particle mass ( $\mu \mathrm{g} / \mathrm{ml})$ and b) particle surface area per well $\left(\mathrm{cm}^{2} /\right.$ well $)$. The doses of 1 and $3 \mathrm{~cm}^{2} /$ well roughly correspond to the doses of 10 and $30 \mu \mathrm{g} / \mathrm{ml}$ for $\mathrm{P} 60$ and 30 and $60 \mu \mathrm{g} / \mathrm{ml}$ for $\mathrm{P} 130$ respectively. $(\mathrm{n}=3)(*=$ statistically different from negative control)

\section{Fig. 6}

Pro-inflammatory response induced by P60 and P130 investigated using the TNF- $\alpha$ assay in RAW 264.7 macrophages. Results are presented using different metrics: a) particle mass $(\mu \mathrm{g} / \mathrm{ml})$ and b) particle surface area per well $\left(\mathrm{cm}^{2} /\right.$ well $)$. The doses of 1 and $3 \mathrm{~cm}^{2} /$ well roughly correspond to the doses of 10 and $30 \mu \mathrm{g} / \mathrm{ml}$ for P60 and 30 and $60 \mu \mathrm{g} / \mathrm{ml}$ for P130 respectively. $(n=3)(*=$ statistically different from negative control. $\Delta=$ statistically different between the indicated groups) 


\section{FIGURES}

Fig. 1

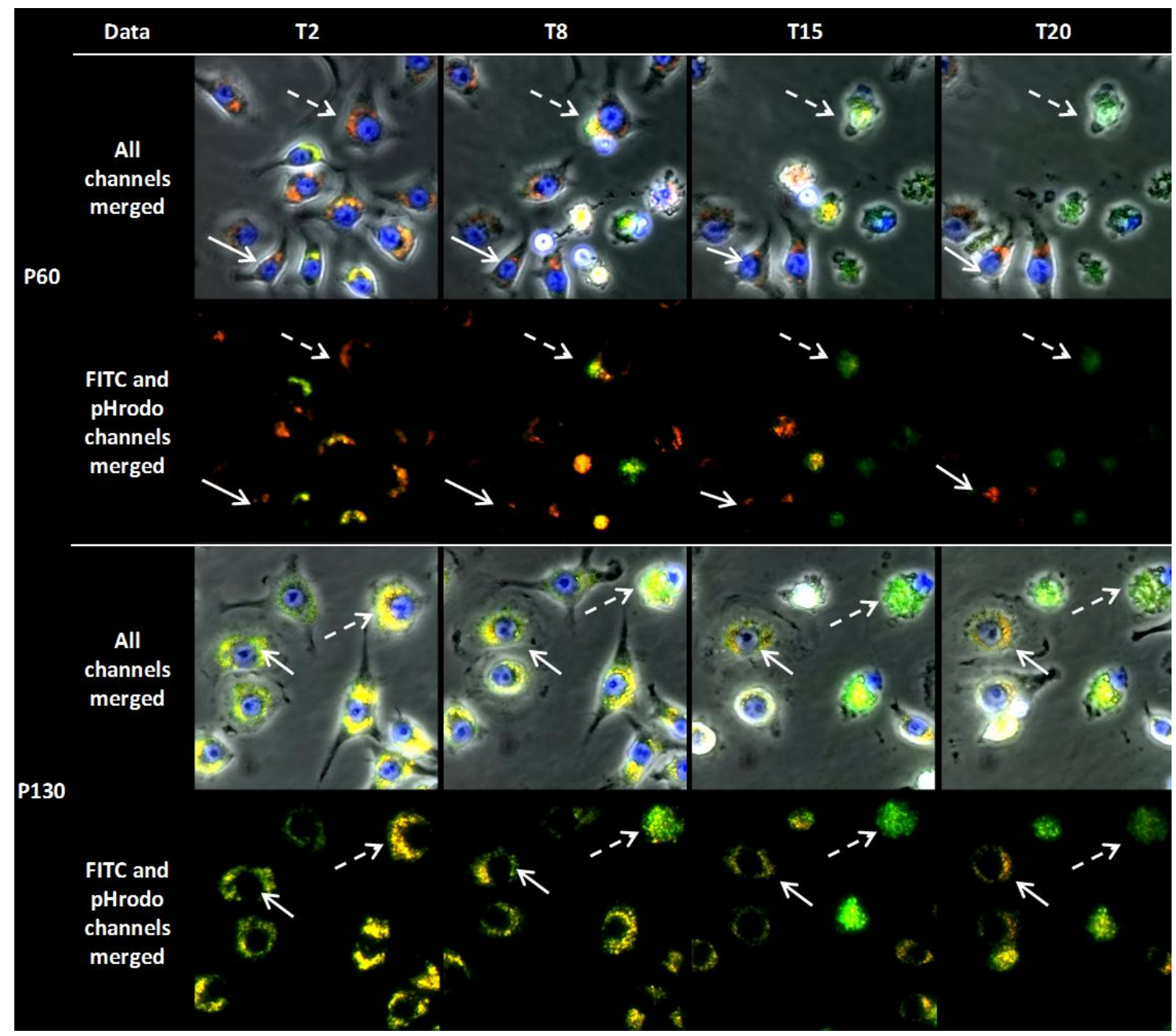


Fig. 2

(a)

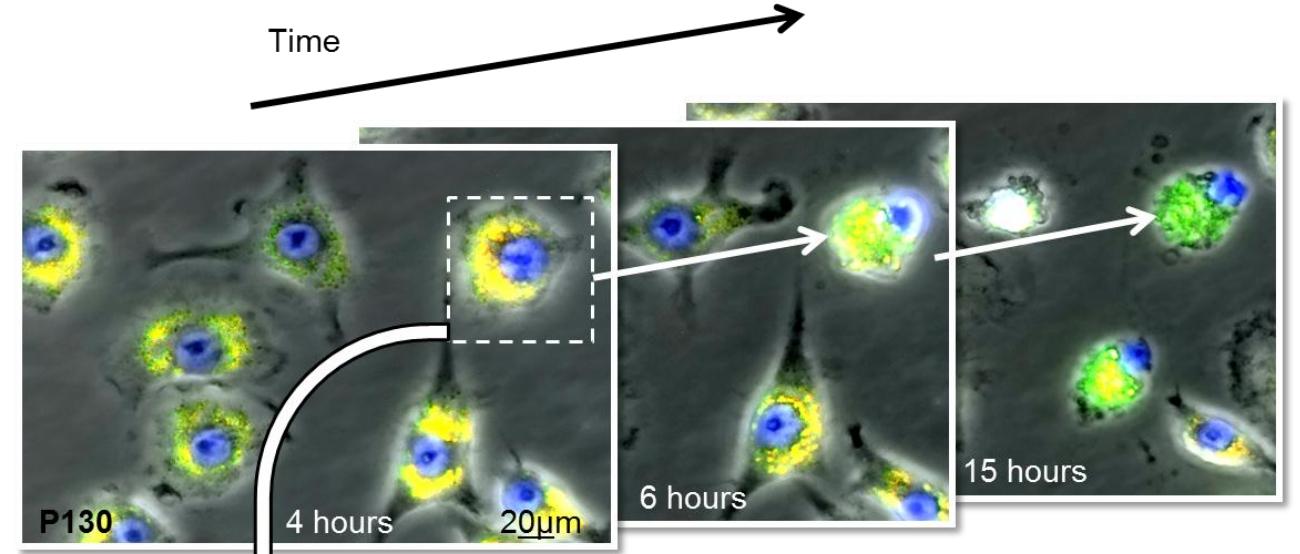

(b)

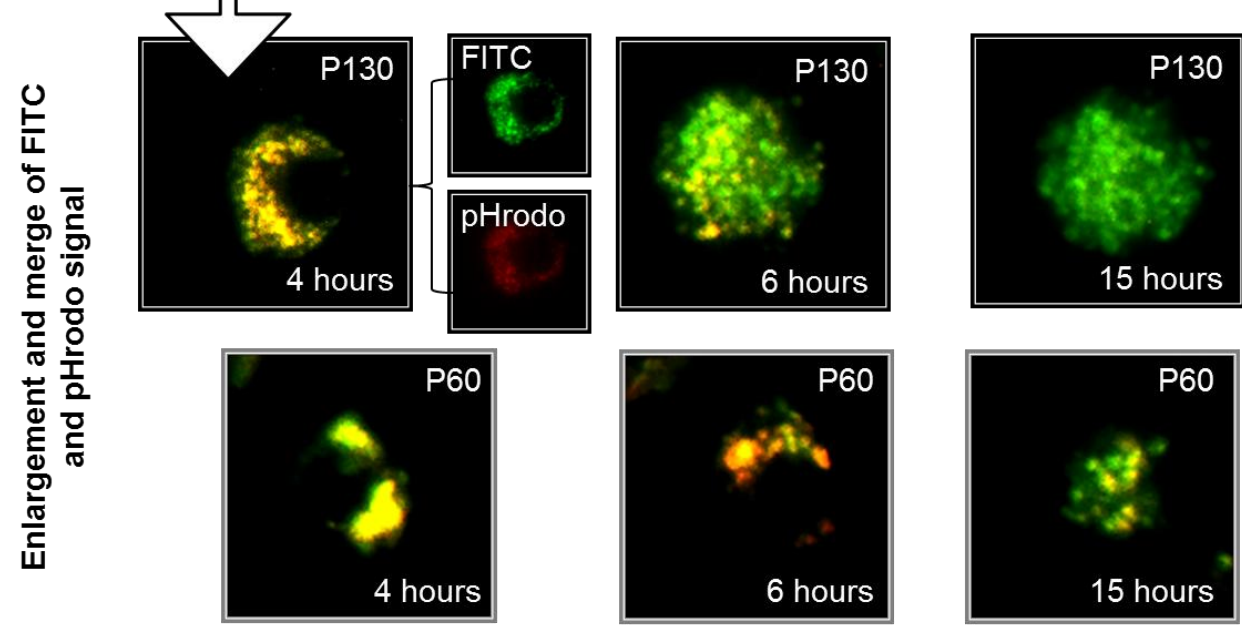

(c)

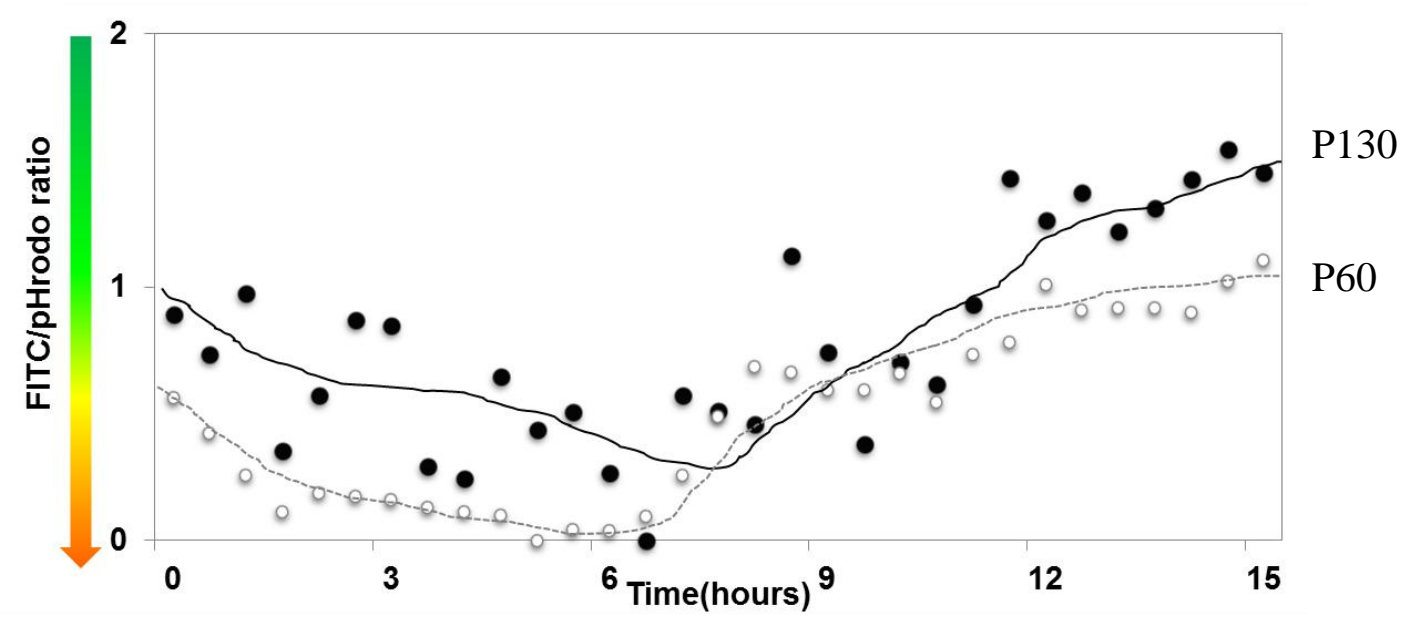


Fig. 3

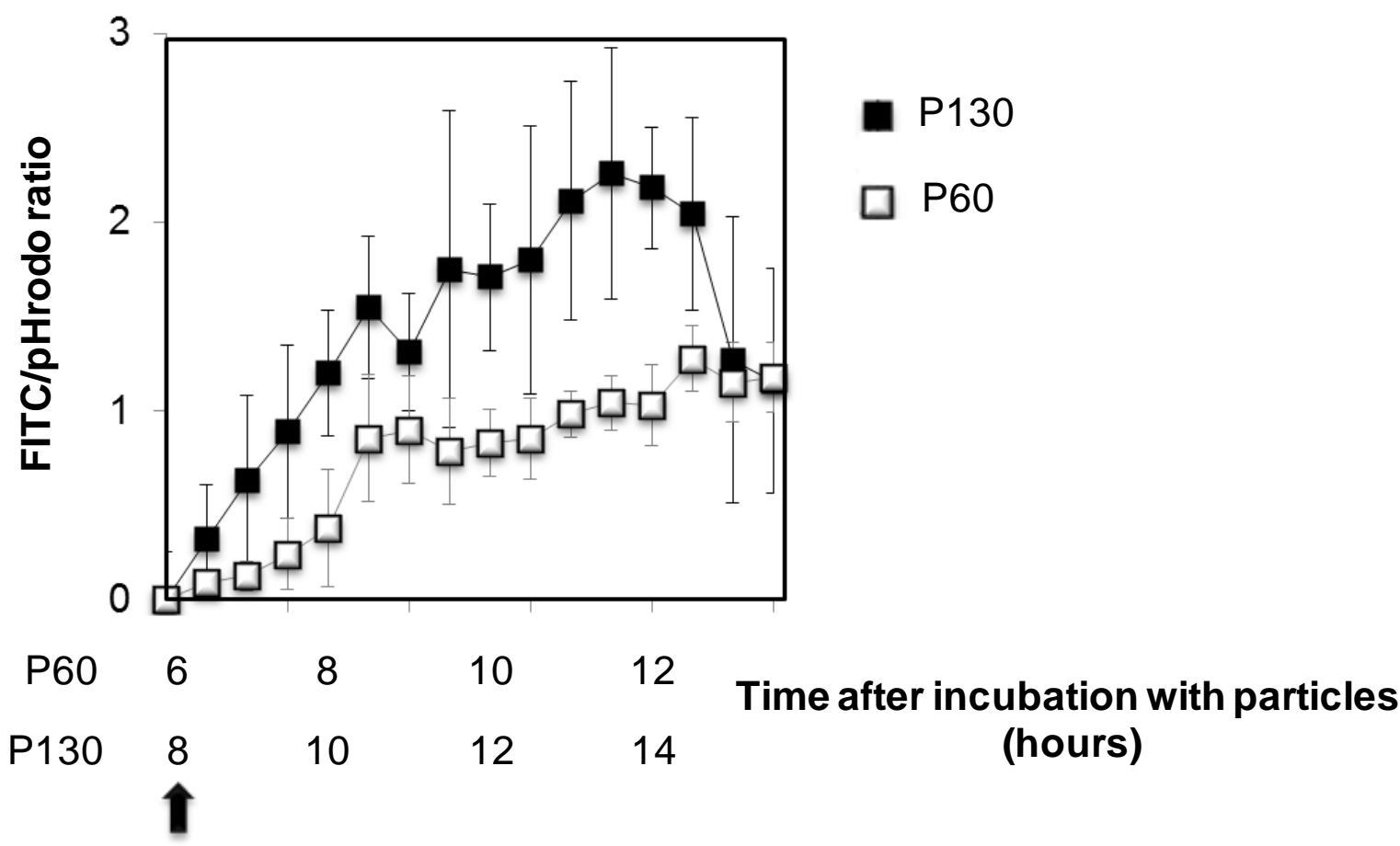

Cell death beginning 
Fig. 4

(a)

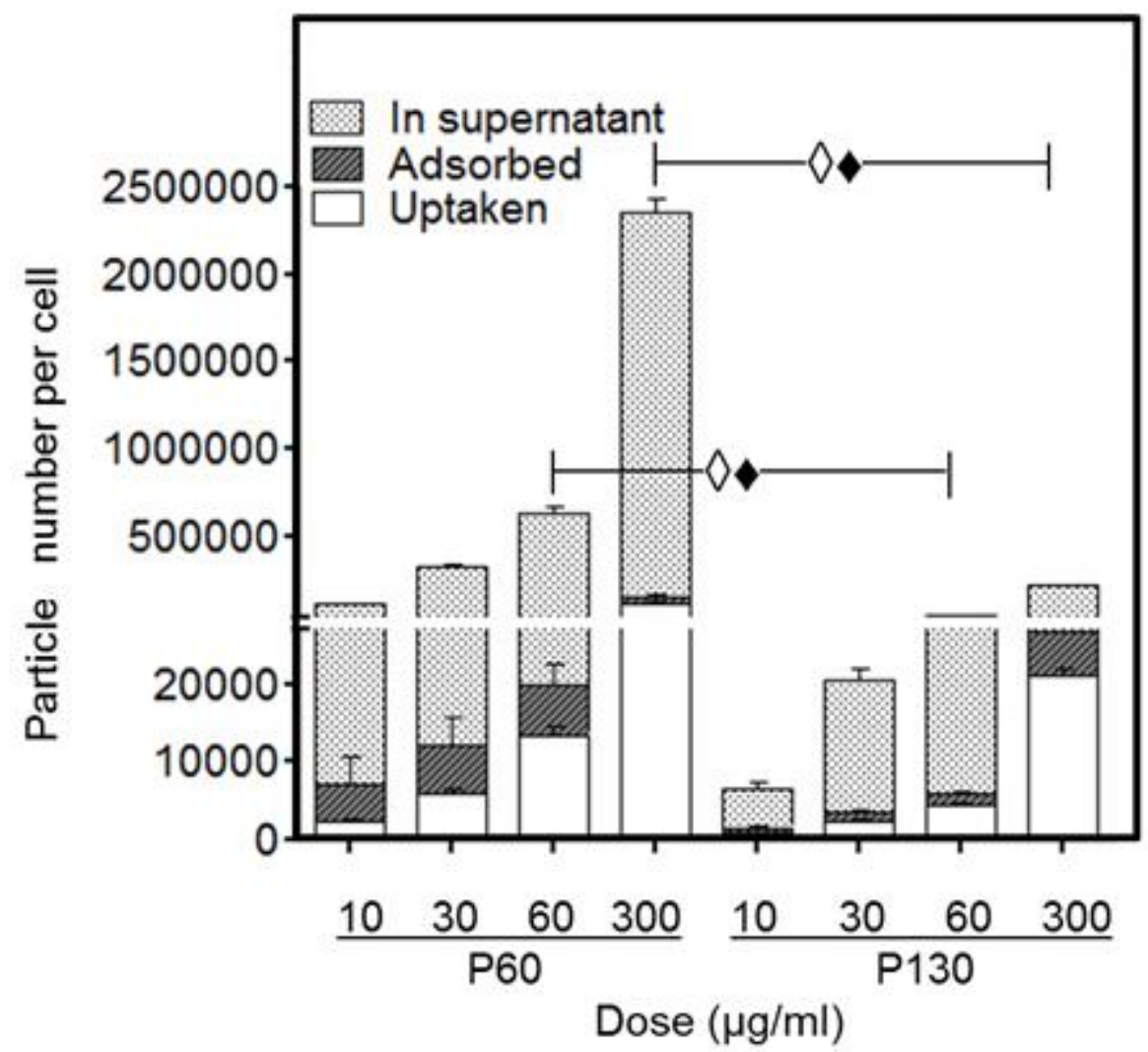

(b)

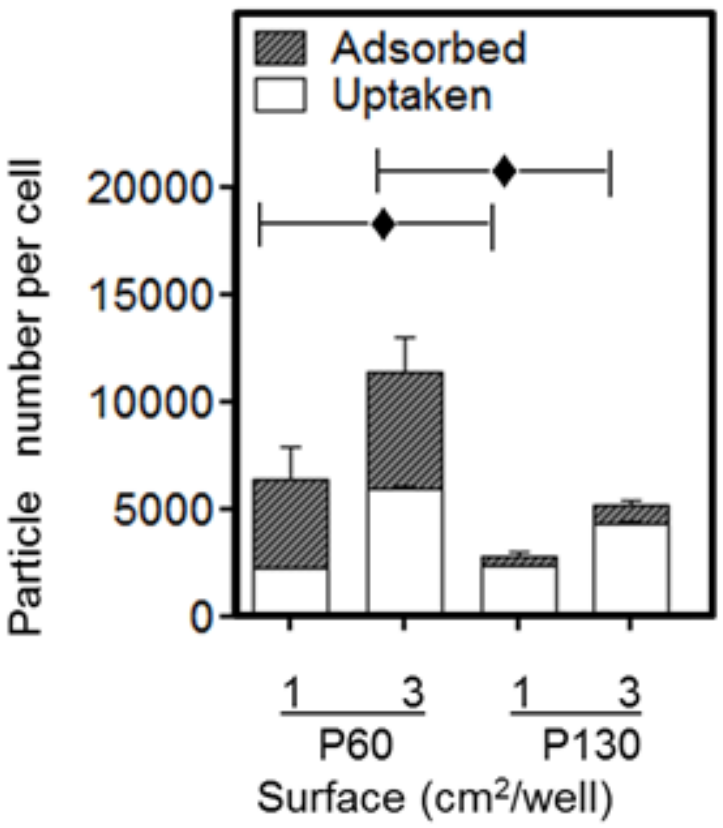


Fig. 5
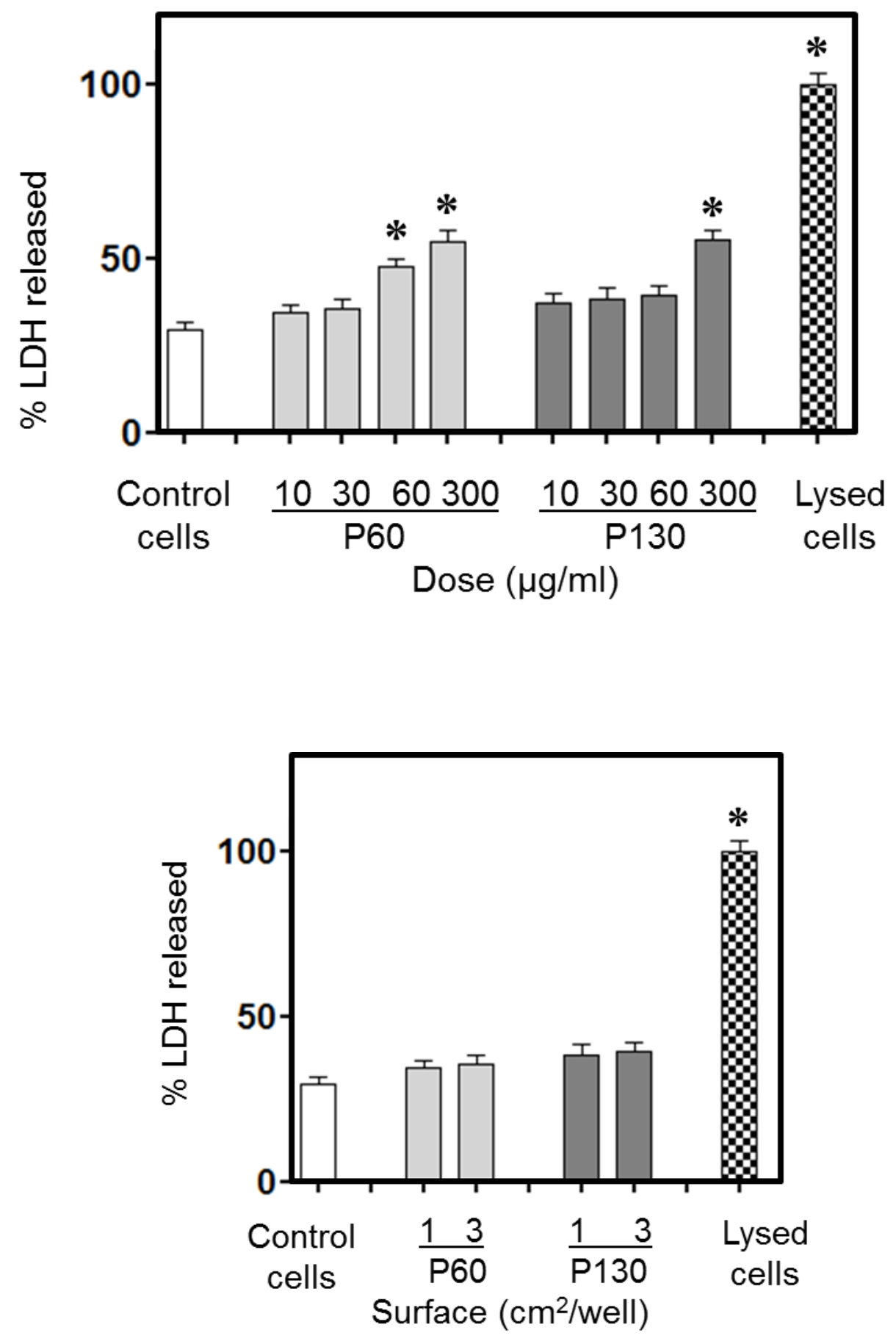
Fig. 6

(a)

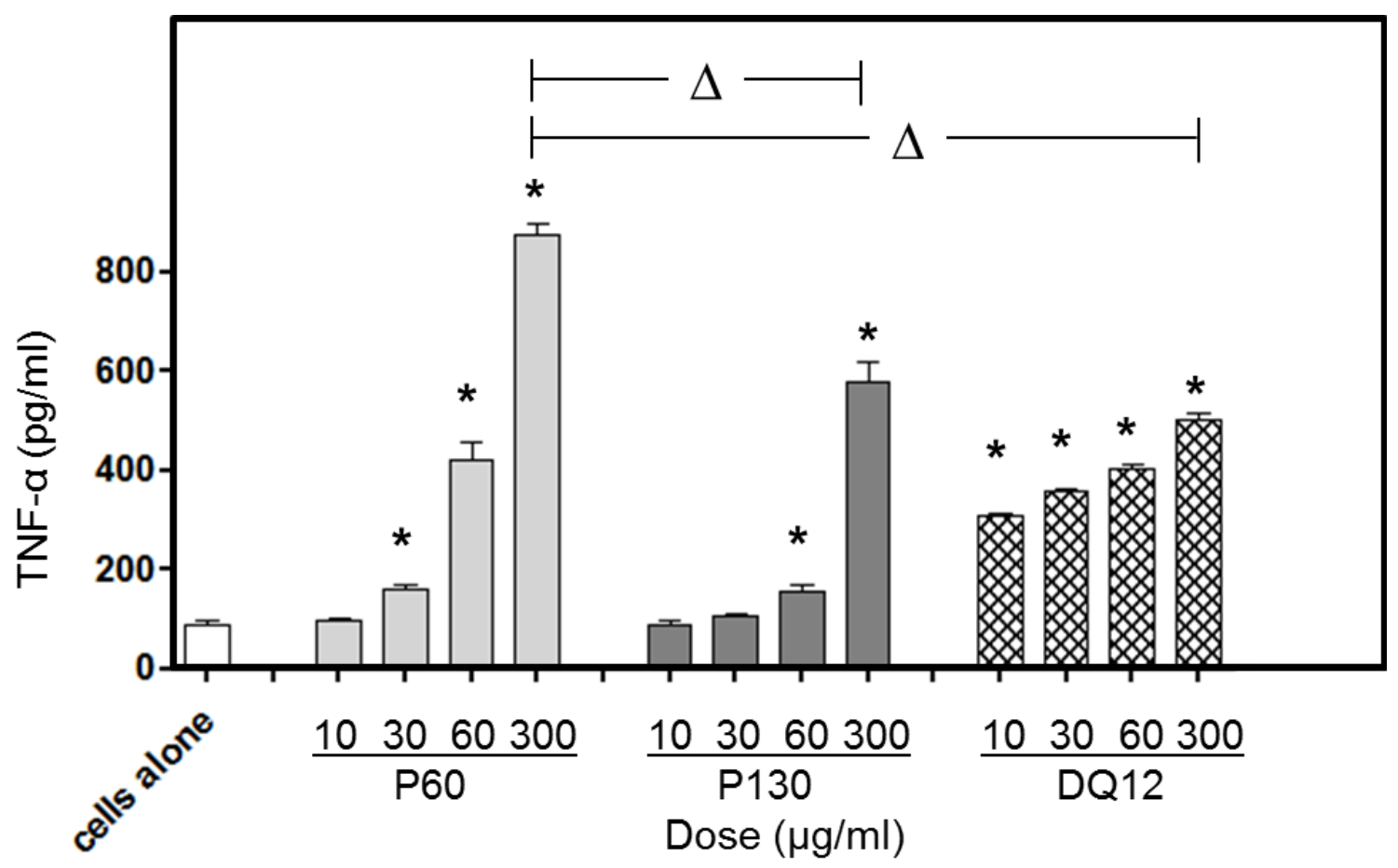

(b)

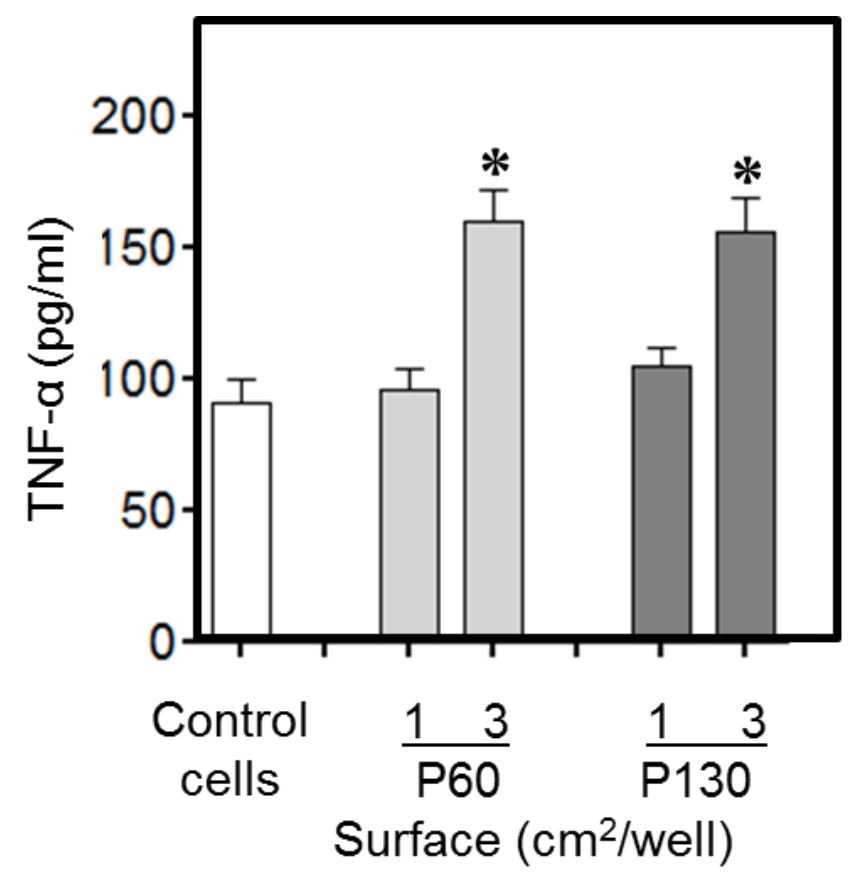


Table 1 Summary of particle characteristics at $100 \mu \mathrm{g} / \mathrm{ml}$.

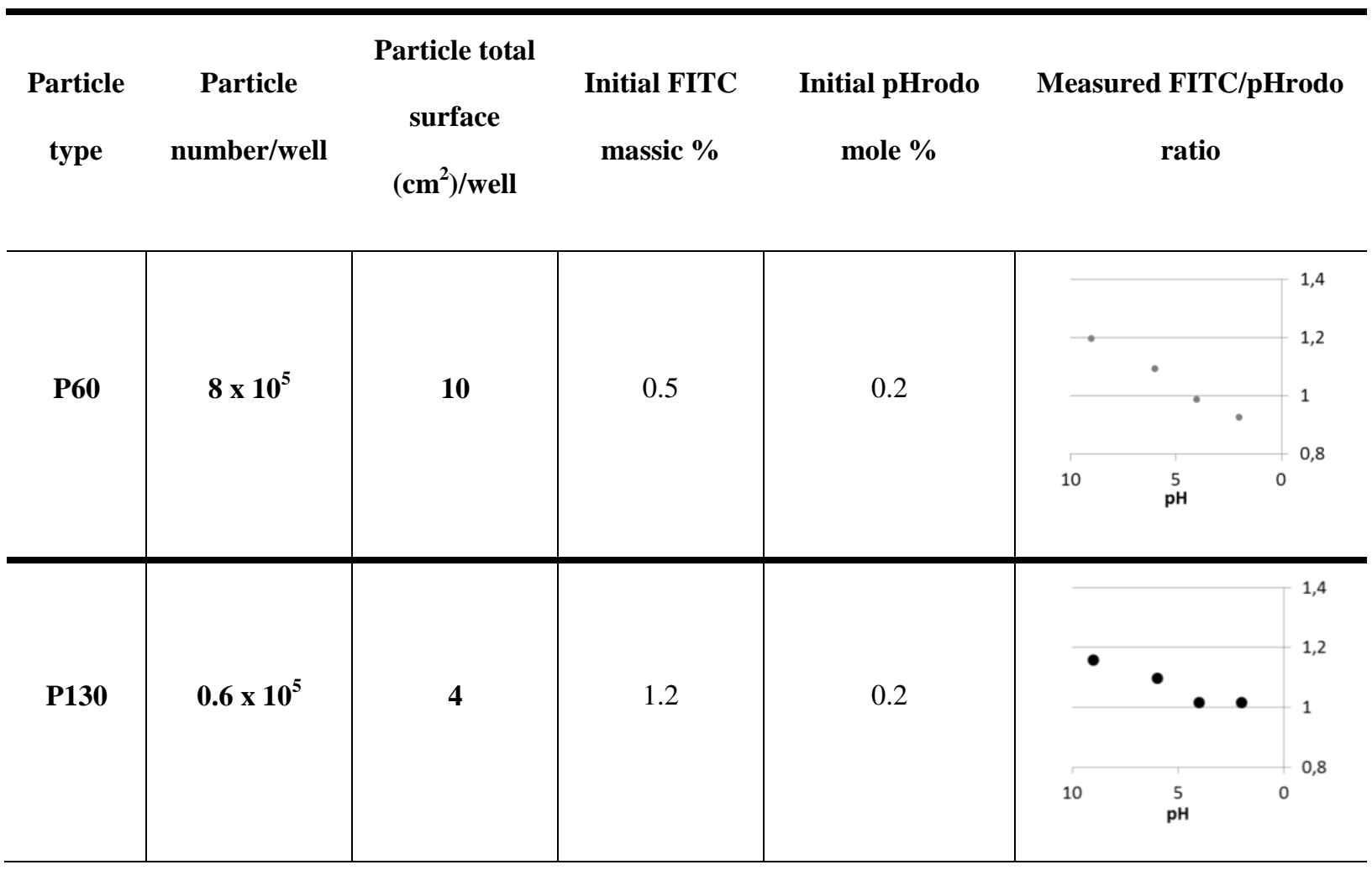

Table 2 Physico-chemical features of the particles used in the present study (Pdi = Polydispersity index).

\begin{tabular}{|c|c|c|c|c|c|}
\hline Method & SEM & \multicolumn{4}{|c|}{ DLS } \\
\hline \multirow{2}{*}{$\begin{array}{l}\text { Particle } \\
\text { characteristic }\end{array}$} & \multirow{2}{*}{$\begin{array}{l}\text { Geometric } \\
\text { diameter }\end{array}$} & \multicolumn{2}{|c|}{$\begin{array}{c}\text { Hydrodynamic diameter } \\
\text { (nm) }\end{array}$} & \multicolumn{2}{|c|}{$\begin{array}{l}\text { Zeta potential } \\
\qquad(\mathrm{mV})\end{array}$} \\
\hline & & in water & in DMEMc & in water & in DMEMc \\
\hline P60 & $62 \pm 10 \mathrm{~nm}$ & $\begin{array}{c}122 \pm 1 \\
(\text { Pdi } 0,07)\end{array}$ & $\begin{array}{c}71 \pm 2 \\
(\text { Pdi } 0,15)\end{array}$ & $-44,5 \pm 2,3$ & $-164 \pm 13$ \\
\hline P130 & $140 \pm 6 \mathrm{~nm}$ & $\begin{array}{c}183 \pm 3 \\
(\text { Pdi } 0,03)\end{array}$ & $\begin{array}{c}123 \pm 2 \\
(\text { Pdi } 0,17)\end{array}$ & $-44,4 \pm 0,4$ & $-179 \pm 17$ \\
\hline
\end{tabular}


Table 3 Semi-quantification of particle uptake by cells over time by time-lapse microscopy. Macrophages were incubated with P60 and P130 at $300 \mu \mathrm{g} / \mathrm{ml}$. Macrophages initially exhibited homogeneous cytoplasm and green particles adsorbed at their membrane, and then activated macrophages cytoplasms contained yellow to red particles depending on $\mathrm{pH}$ of phagocytic vesicles.

\begin{tabular}{|c|c|c|c|c|c|c|}
\hline $\begin{array}{c}\text { Particle } \\
\text { type }\end{array}$ & Observation & $\mathbf{T 2}$ & T8 & T15 & $\mathbf{T 2 0}$ & $\begin{array}{c}\text { Schematic repartition } \\
\text { of particles in cells }\end{array}$ \\
\hline \multirow{3}{*}{$\mathbf{P 6 0}$} & Cells containing particles in phagosomes & $34 \%$ & $29 \%$ & $0 \%$ & $0 \%$ & \multirow{3}{*}{$\underbrace{23}_{2 n}$} \\
\hline & Cells containing particles in phagolysosomes & $66 \%$ & $38 \%$ & $24 \%$ & $14 \%$ & \\
\hline & Dead cells after release of particles & $0 \%$ & $33 \%$ & $76 \%$ & $86 \%$ & \\
\hline \multirow{3}{*}{ P130 } & Cells containing particles in phagosomes & $83 \%$ & $68 \%$ & $42 \%$ & $40 \%$ & \multirow{3}{*}{$\int_{2}^{2}$} \\
\hline & Cells containing particles in phagolysosomes & $17 \%$ & $14 \%$ & $28 \%$ & $16 \%$ & \\
\hline & Dead cells after release of particles & $0 \%$ & $18 \%$ & $30 \%$ & $44 \%$ & \\
\hline
\end{tabular}

